\title{
Dicranomyia (Idiopyga) nigristigma NiELSEN, 1919 (Diptera, Limoniidae) recorded for the first time from calcareous springs in Romania
}

\author{
Lujza Keresztes, Mirela Cîmpean, Karina Battes, Anna Dénes \& Andrei Bogdan Terec
}

\begin{abstract}
Summary: Dicranomyia (Idiopyga) nigristigma NiELSEN, 1919 (Diptera, Limoniidae) is recorded for the first time from Romania. The species was collected in some calcareous springs in the Apuseni Mountains and highlight an overlooked Limoniidae diversity in similar habitats from the karstic area from here.
\end{abstract}

Rezumat: Dicranomyia (Idiopyga) nigristigma NiELSEN, 1919 (Diptera, Limoniidae) este semnalată pentru prima dată din România. Specia a fost colectată de-a lungul unor izvoare calcaroase din Munții Apuseni, și evidențiază o biodiversitate a Limoniidelor încă neexplorată din ecosistemele carstice de la noi.

Key words: Limoniidae, Diptera, new record, the Carpathians.

\section{Introduction}

Idiopyga SAVCHENKo, 1987 is a subgenus of the species-rich genus Dicranomyia STEPHENS, 1829, separated from all other representatives of the genus because of the unusually complex hypopygium of the males (SAVCHENKo 1987). In present a number of 27 species and subspecies were recorded from this subgenus in the Holarctic area. However, few individual species should have rather restricted distribution (OOSTERBroek 2021). A number of 19 species and subspecies are present in Europe, with relatively few species (only six) restricted to the continental spring fens or marshy habitats at different altitudes. The rest of the species (13) has larger distribution from the western Palearctic to the Nearctic regions (OOSTERBROEK 2021).

Records of Idiopyga species in Romania are rather sporadically. The first record of Dicranomyia (Idiopyga) stigmatica (MeIGeN, 1830) was published in 1986 from the northern part of the Eastern Carpathians (Valea Putnei, Rarău-Giumalău Mountains) by ERHAN in 1986 and cited later by various sources (ex. UJvÁrosI 2007). Later a new country record of the species was added from a marshy area around Voslobeni (Gheorgheni Depression, the Eastern Carpathians) (UJvÁrosi et al. 2011). Quite recently, new distribution data was recorded for Dicranomyia (Idiopyga) alpina BANGERTER, 1948, swept from marshy vegetation near a high-altitude lake from the Eastern Carpathians, the Iezer Lake, at 1735 m a.s.1. (Călimani Mountains) (Kolcsár et al. 2021).

\section{Material and methods}

The two male specimens were collected both in the Apuseni Mountains around some calcareous spring fens: 1 male, Bihor Mts., Valea Drăganului, Ciripa spring complex, $1050 \mathrm{~m}$ a.s.1., $46.693^{\circ} \mathrm{N}$, $27.675^{\circ} \mathrm{E}, 10^{\text {th }}$ October, 2021 (leg. A. DÉNes); 1 male, Gilău Mountains, Valea Someşului Cald, spring fen near Smida, $1023 \mathrm{~m}$ a.s.1., $46.643^{\circ} \mathrm{N}$, $22.876^{\circ}$ E, $26^{\text {th }}$ September, 2021 (leg. L. KereszTES). Diptera materials were collected using sweep net and searching the hygrophilous vegetation near springs and brooks. Individuals of $D$. (I.) nigristigma were preserved dry (one male) and in ethanol 95\% (one male) in the reference Diptera collection of Faculty of Biology and Geology (DCFBG), Babeș-Bolyai University, Cluj Napoca, Romania.

High resolution photos of the wings were taken with a stereomicroscope (Olympus SZ51) equipped with a digital camera in dark and white background (Canon EOS 750D). Photos of the male hypopygium and details of some genital structure were taken in glycerol without coverslip using a compound microscope (Olympus CX23) with a high-resolution camera (Canon EOS 750D). As for stacking software, we used Zerene Stacker software. Male genitalia was left overnight in $10 \%$ potassium hydroxide $(\mathrm{KOH})$ and for one hour in undiluted glacial acetic acid, to neutralise and wash out the soap that was created from the soft tissues. The male genitalia was then transferred to a larger amount of glycerol to wash out the acid. Afterwards, they were transferred to a drop of glycerol on a slide with rounded excavation. The 
genitals were dissected, the parts were oriented using the stereomicroscope, and then the slide was carefully transferred to the compound microscope for the taking of photos. Stacking results in general consist of 5-10 single exposures with the stereomicroscope and of 10-50 exposures with the compound microscope.

\section{Results}

Dicranomyia (Idiopyga) nigristigma NIELSEN, 1919 is recorded for the first time for the Limoniidae fauna of Romania.

The two male individuals were collected as part of a monitoring project focusing on the biodiversity and distribution of aquatic insects in springs and headwaters from the Apuseni Mountains, Romania, collecting both adults and larvae of a large number of other aquatic invertebrate taxa.

Male individuals were identified using reference literature sources (Thomas 1972, MENDL 1985, Podenas et al. 2006). Right wing and details in the male hypopygium of specimen collected from a marshy spring near Smida, Someşul Cald River area, the Apuseni Mountains is presented in fig. 1 .

A map with known distribution data on $D$. (Idiopyga) from Romania is presented in fig. 2.

\section{Discussion}

Dicranomyia (Idiopyga) nigristigma is similar to the close related $D$. (Idiopyga) stigmatica, but separable based on the conspicuous black spot on the wings and details in the male genital parts (fig. 1). However, the two species are ecologically highly distinct. D. (I.) nigristigma is confined to shaded calcareous seepages or peat bogs in the woodland area, where the semiaquatic larvae live mostly in mosses (STUBBS 2003). In Romania, the two individuals were collected in similar habitats, the spring sectors of the rivers Someşul Cald and Valea Drăganului are abundant in calcareous springs with peat bogs and marshy margins. In contrast, $D$. (I.) stigmatiga avoid calcareous waters, recorded from the exclusively acid environment (Voșlobeni, După Luncă Marsch and from the Putna valley, both the Eastern Carpathians), with predominated volcanic rocks (ERHAN 1986, UJvÁrosI 2007, UJvÁrosi et al. 2011).

Diptera fauna of spring fens in Romania is poorly investigated. However, data on different rare or endemic Tipuloidea species (Tipulidae, Limoniidae, Pediciidae) with aquatic development stages in the karstic area of the Apuseni Mountains, suggests that these habitats are of high conservation value (DENES et al. 2016). During our investigation, a number of other habitat specialist Tipuloidea species were collected, too, together with $D$. (I.) nigristigma. These species belongs to Tipulidae family, like Tipula (Savchenkia) alpha DE JONG, 1994, T. (Platytipula) luteipennis MeIGEN, 1830. Similar habitat specialist Limoniidae species were also collected here, like $D$. (Melanolimonia) morio (FABRICIUS, 1787).

Dicranota (I.) nigristigma is an early autumn species. The fact that the species was collected in falls, together with a large number of other rare
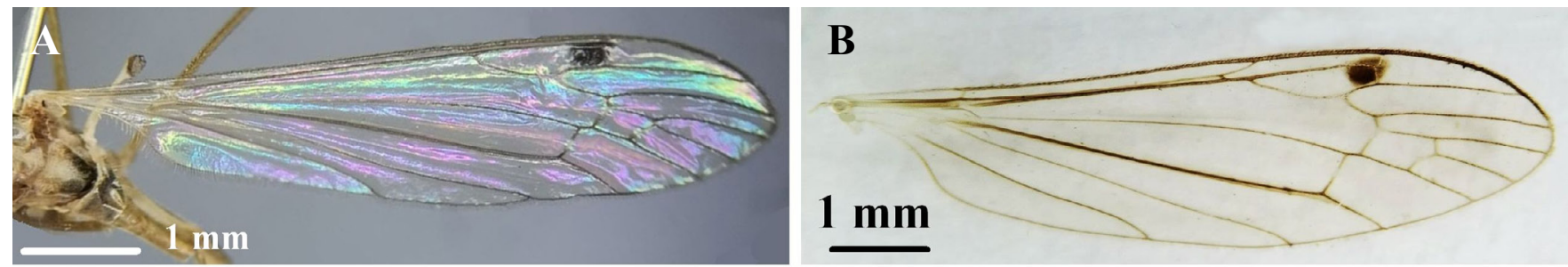

C

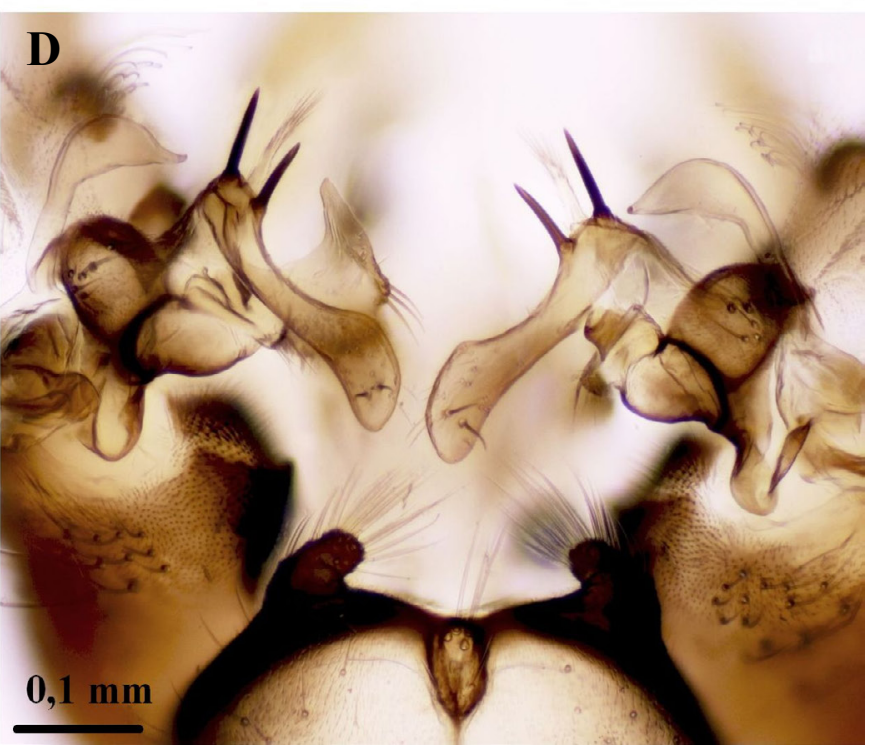

Fig. 1. Dicranomyia (Idiopyga) nigristigma, male. A. Right wing with wing interference in black background. B. Same wing with white background. C. End of the abdomen, dorsal, with genital appendages. D. Male genitalia, dorsal, details. 


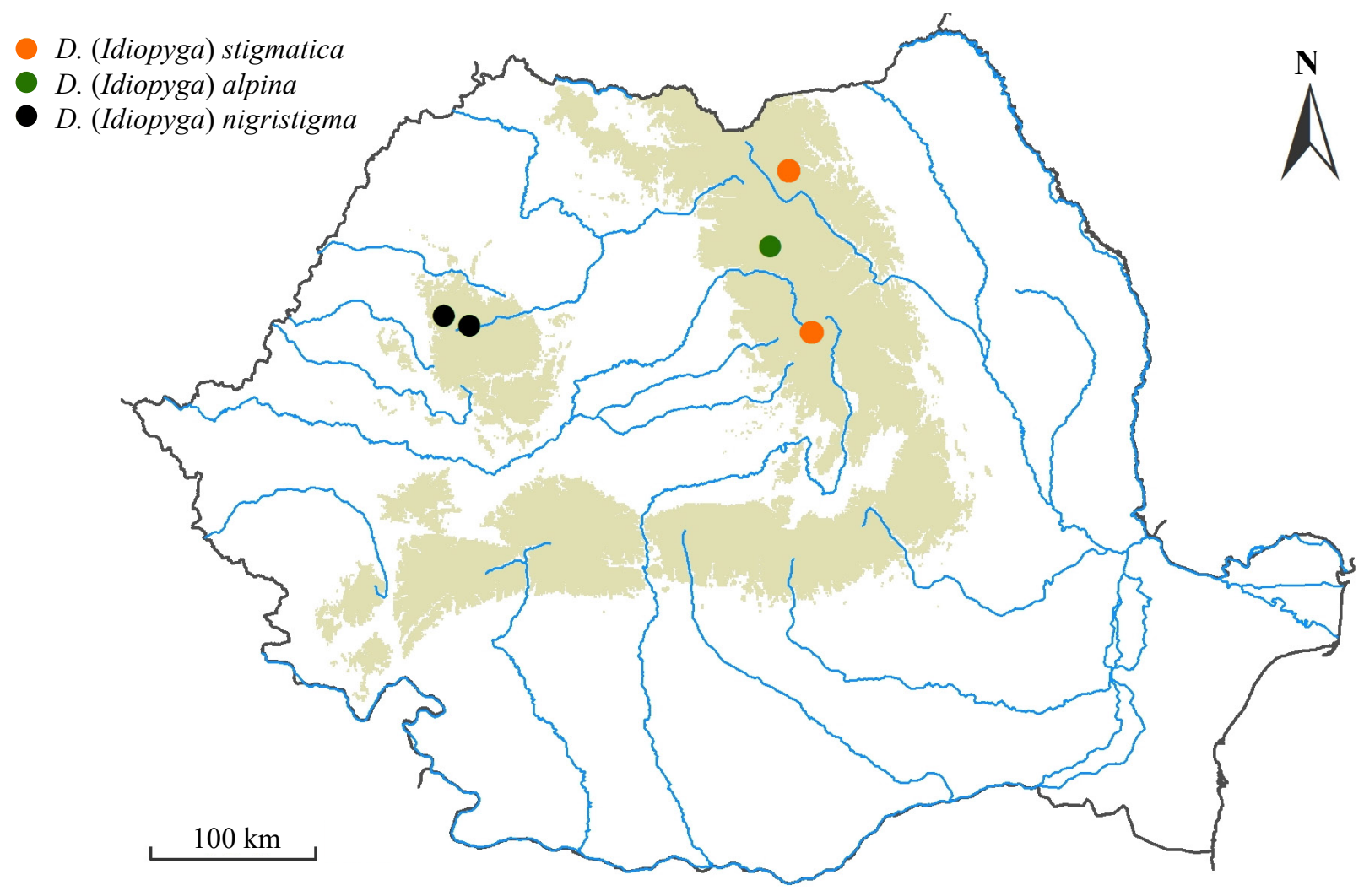

Fig. 2. Known distribution of the subgenus D. (Idiopyga) in Romania. Black dots - new additions; orange and green dots literature data.

Tipuloidea species in Romania, suggest the presence of an important underestimated Tipuloidea diversity from here. It is necessary for the future to intensify several autumnal collecting campaigns, including large number of similar habitats to detect the real distribution of the species in Romania.

\section{Conclusions}

$D$. (I.) nigristigma was recorded for the first time in Romania. However, the presence of this habitat specialist taxa in the Apuseni Mountains is of high conservative value. These vulnerable habitats are at increasing risk due to intensive deforestation and uncontrolled water supply from these springs, required by the increasing tourist activity in the area.

\section{Acknowledgements}

The present work received financial support from a national grant offered by the Executive Unit for Financing Higher Education, Research, Development and Innovation, UEFSCDI, of the Ministry of Education and Research, PNIII-P2-2.1-PED-2019-0214; nr. 476PED/2020.

We would like to thank the Apuseni Mountains National Park Authority for allowing us to collect in the park area.

\section{References}

DÉNEs A.-L., KolcsáR L.-P., TÖrÖK E. and Keresztes L. (2016) Phylogeography of the micro-endemic Pedicia staryi group (Insecta: Diptera): evidence of relict biodiversity in the Carpathians. Biological Journal of the Linnean Society 119: 719-731.

Kolcsár L.-P., Oosterbroek P., Gavryushin D.I., Olsen K.M., Paramonov N.M., Pilipenko V.E., Starý J., Polevor A., Lantsov V.I., Eiroa E., Andersson M., Salmela J., Quindroit C., d'Oliveira M.C., Hancock E.G., Mederos J., Boardman P., Vittanen E. and WatANABE K. (2021). Contribution to the knowledge of Limoniidae (Diptera: Tipuloidea): first records of 244 species from various European countries. Biodiversity Data Journal 9 (e67085): 1-247.

MendL H. (1985) Zur Identitat von Dicranomyia nigristigma Nielsen, 1919 (Diptera Nematocera: Limoniidae). Articulata 2: 199-204. Oosterbroek, 2021.

Oosterbroek P. (2021) Catalogue of the craneflies of the World (Diptera, Tipuloidea: Pediciidae, Limoniidae, Cylindrotomidae, Tipulidae). http://ccw.naturalis.nl. Accessed on: 2021-11-01.

Podenas S., Geiger W., Haenni J.-P. and Gonseth Y. (2006) Limoniidae \& Pediciidae de Suisse. Fauna Helvetica 14: 1-375 (in French and English, introduction also in German).

Thomas A.G.B. (1972) Sur quatre Limonia (Dicranomyia) europeennes peu connus (Diptera, Tipulidae). Annales de Limnologie 8: 63-70.

SAVCHENKo E.N. (1987) Idiopyga Savtshenko nom. nov. (Diptera, Limoniidae). Vestnik Zoologii 1987(6): 81 (in Russian).

StubBs A.E. (1993) Terrestrial invertebrate survey of Strover Park SSSI, South Devon. English Nature Research Reports 125: xxx-xxx.

Ujvárosi L. (2007) Suprafamilia Tipuloidea. In: Moldovan O.T. (ed.), Checklist of Romanian fauna (terrestrial 
and freshwater species). Institutul de Speologie Emil Racoviță, Cluj: 228-234.

Ujvárosi L., PóTi T., Kolcsár L.-P. (2011) Lószúnyogszerü dipterak (Diptera, Tipuloidea) élőhelypreferenciája és szezonalis diverzitása a Vaslábi rétlápban és annak környékén (Keleti Kárpátok) [Tipuloidea in the Dupa
Lunca fen complex near Voslobeni]. In: MARKó B. and SÁRKÁNY-KIss E. (eds.): A Gyergyói-medence: egy mozaikos táj természeti értékei [Gheorgeheni Depression: evaluating the natural capital of a mosaic landscape]. Presa Universitară Clujeană/Cluj University Press: 101-118 (in Hungarian with English abstract).
Lujza Keresztes

Hungarian Department of Biology and Ecology, Faculty of Biology and Geology, Center for Systemic Biology, Biodiversity and Bioresources ' $3 \mathrm{~B}$ ', Laboratory of Advanced Hydrobiology and Biomonitoring (LabHAB), Babeș-Bolyai University, Clinicilor 5-7, Cluj-Napoca, RO-400006, Romania

E-mail: lujza.keresztes@ubbcluj.ro

\section{Anna DÉNES}

Center for Systemic Biology, Biodiversity and Bioresources '3B', Laboratory of Advanced Hydrobiology and Biomonitoring (LabHAB), Integrative Biology Doctoral School, Faculty of Biology and Geology, Babes-Bolyai University, Clinicilor 5-7,

Cluj-Napoca, RO-400006, Romania

E-mail: anna.denes@ubbcluj.ro

\section{Mirela CîMPEAn}

Center for Systemic Biology, Biodiversity and Bioresources ' $3 \mathrm{~B}$ ', Laboratory of Advanced Hydrobiology and Biomonitoring (LabHAB), Department of Taxonomy and Ecology, Faculty of Biology and Geology, Babeș-Bolyai University, Clinicilor 5-7, Cluj-Napoca, RO-400006, Romania E-mail:mirela.cimpean@ubbcluj.ro

\section{Andrei Bogdan TereC}

Center for Systemic Biology, Biodiversity and Bioresources ' $3 \mathrm{~B}$ ', Laboratory of Advanced Hydrobiology and Biomonitoring (LabHAB), Integrative Biology Doctoral School, Faculty of Biology and Geology, Babes-Bolyai University, Clinicilor 5-7, Cluj-Napoca, RO-400006, Romania E-mail: andrei.terec@ubbcluj.ro

\section{Karina BATTES}

Center for Systemic Biology, Biodiversity and Bioresources ' $3 \mathrm{~B}$ ', Laboratory of Advanced Hydrobiology and Biomonitoring (LabHAB), Department of Taxonomy and Ecology, Faculty of Biology and Geology, Babeș-Bolyai University, Clinicilor 5-7, Cluj-Napoca, RO-400006, Romania E-mail: karina.battes@ubbcluj.ro

Received: 01.11.2021

Accepted: 15.11.2021

Published online: 31.12 .2021

Article number: ER25202104

doi: 10.24193/entomolrom.25.4 